\title{
The Effect of Infant Massage on Infant Weight Gain
}

\author{
$1^{\text {st }}$ I A Anggarini \\ Lecturer of the Midwifery Study \\ Program \\ STIKes Muhammadiyah Palembang \\ Palembang, Indonesia \\ anggiinge@gmail.com \\ $4^{\text {th }}$ L Susanti \\ Lecturer of the Midwifery Study \\ Program \\ STIKes Muhammadiyah Palembang \\ Palembang, Indonesia
}

\author{
$2^{\text {nd }} \mathrm{R}$ Andriani \\ Lecturer of the Midwifery Study \\ Program \\ STIKes Muhammadiyah Palembang \\ Palembang, Indonesia
}

\author{
$3^{\text {rd }} \mathrm{C}$ Purwanti \\ Lecturer of the Midwifery Study \\ Program \\ STIKes Muhammadiyah Palembang \\ Palembang, Indonesia
}

\begin{abstract}
Some of the benefits of baby massage include increasing appetite, doubling the benefits of exclusive breastfeeding, increasing body weight, increasing endurance, making babies sleep more soundly, and fostering attachment between parents and children. This research aims to determine the effect of infant massage on weight gain in infants at the Independent Practice of Midwife Zuniawati and Misni Herawati in 2019. This study uses a quantitative approach; the method used in this study is a quasiexperimental type of pre-posttest control group design. The population is newborns in PMB Zuniawati and Misni. Sample 30 treated 30 controls. The sampling technique was purposive sampling. The mean difference between before and after being given a baby massage in the intervention group was $263.33 \mathrm{gr}$. The difference in the mean between before and after the control group increased by $78.33 \mathrm{gr}$. The increase in infant weight in the intervention group was higher than in the control group. Statistical test results were significant differences between the weight gain of infants before and after treatment both in the treatment group and the control group.
\end{abstract}

Keywords-Infant, Massage, Weight Gain

\section{INTRODUCTION}

Riskesdas (2013) stated nationally, the prevalence of underweight in 2013 was 19.6 percent, consisting of 5.7 percent of poor nutrition and 13.9 percent of undernutrition. When compared with the national prevalence rate in 2007 (18.4\%) and in 2010 (17.9\%), it appears to be increasing. Changes are mainly in the prevalence of malnutrition, from 5.4 percent in 2007, 4.9 percent in 2010, and 5.7 percent in 2013. One thing that can be done in dealing with weight problems is regulating diet or nutrition. One of the causes of weight problems is a child's decreased appetite. This can be overcome by giving supplements or vitamins to children or stimulation and stimulation. One of the stimuli and stimuli recommended is a baby massage.

Baby massage can be classified as a touch stimulation application because, in baby massage, there are touch elements in the form of affection, attention, voice or speech, eyesight, movement, and massage. This stimulation will stimulate the development of the structure and function of brain cells (Soedjatmiko, 2006). Currently, there have been many studies that state that baby massage has many benefits, both physically and emotionally. Some of the benefits of baby massage are including increasing appetite, doubling the benefits of exclusive breastfeeding, increasing body weight, increasing endurance, making babies sleep more soundly, and fostering attachment between parents and children. Some studies say baby massage can stimulate the vagus nerve, where this nerve increases intestinal peristalsis so that emptying of the stomach increases, thereby stimulating the baby's appetite. On the other hand, massage also increases blood circulation and increases cell metabolism; from the series, the baby's weight will increase. Roesli cites Field and Scafidi research that is in premature infants who performed massage $3 \times 10$ minutes for 10 days, weight gain every day $20 \%-47 \%$ and in term infants aged 1-3 months massaged 15 minutes, twice a week for six weeks, gaining weight is better than not getting a massage. From the description above, looking at weight problems and the benefits of baby massage on weight loss and the results of several previous studies, the author is very interested in research to study the effect of baby massage on changes in baby's weight. The authors hope this research will be useful for parents and even energy workers. Medical in helping to improve the quality of health, because baby massage certainly has many conveniences and benefits and can be done by all groups from the upper or middle to lower classes. The purpose of this study was to determine the effect of infant massage on weight gain in infants at the Independent Practice of Midwife Zuniawati and Misni Herawati in 2019.

\section{METHOD}

This research uses a quantitative approach; the method used in this study is a quasi-experimental type of preposttest control group design. The study population was 
newborn babies at PMB Zuniawati and Misni H. The sample of this study was 30 treatments 30 controls. The sampling technique was purposive sampling. In the baby massage treatment group will be carried out by midwives who have been certified to do baby massage, baby massage is carried out for ten consecutive days from the time the baby is born until the 10th day with a duration of 30 minutes each massage session using VCO (Virgin Coconut Oil). Researchers will conduct a home visit to measure weight gain in infants and evaluate infant massage that has been done on day 10. Secondary data were obtained from patient status at PMB Zuniawati and Misni Herawati, whereas the control group was not massaged. Mothers included in the control group will be given leaflets about daily care for newborns. After the research took place, the researchers gave counseling and demonstrations regarding infant massage to the control group, so that both respondents still received benefits related to this study. The baby's weight was measured using a manual scale OneMed Baby Scale OD 230.

\section{RESULT}

A. Characteristics of Respondents through Univarible Analysis

Univariable analysis results, which are seen from several variables, obtained a description of the characteristics of the research subjects treatment groups who were given baby massage and the control group who were not given baby massage.

TABLE 2. PAIRED T. TEST FOR DIFFERENCES IN INFANT WEIGHT BEFORE AND AFTER TREATMENT IN THE TREATMENT AND CONTROL GROUPS

\begin{tabular}{|c|c|c|c|c|c|c|}
\hline \multirow[t]{3}{*}{ Variable } & \multicolumn{2}{|c|}{ weight gain } & \multirow{3}{*}{$\begin{array}{c}\Delta \\
\text { Mean }\end{array}$} & \multirow{3}{*}{$95 \% \mathrm{CI}$} & \multirow{3}{*}{$t$-test } & \multirow{3}{*}{$p$ value } \\
\hline & Pre test & Post test & & & & \\
\hline & Mean \pm SD & Mean \pm SD & & & & \\
\hline $\begin{array}{l}\text { Intervention } \\
\text { group }\end{array}$ & $3.510 \pm 682,9$ & $3.773,3 \pm 662,3$ & $-263,3$ & $-313,8-(-212,8)$ & $-10,67$ & 0,001 \\
\hline Control group & $3.570 \pm 752,1$ & $3.648 \pm 707,2$ & $-78,33$ & $-125,79-(-30,88)$ & $-3,37$ & 0,028 \\
\hline
\end{tabular}

In table 4.2 shows that in the treatment group, the average weight gain of infants before being given a baby massage was 3,510 gr and after being given a baby massage, the baby gained weight on average increased to $3,773.3$ gr. The difference in mean between before and after being given a baby massage is $263.3 \mathrm{gr}$. In the control group, the average baby's weight gain previously was
TABLE 1.FREQUENCY DISTRIBUTION OF RESPONDENT CHARACTERISTICS

\begin{tabular}{|l|c|c|}
\hline \multicolumn{1}{|c|}{ Variable } & $\mathrm{N}$ & $\%$ \\
\hline Baby massage & & 50,0 \\
Given Baby Massage & 30 & 50,0 \\
No baby massage & 30 & \\
\hline Mother's age & & 90,0 \\
Low risk & 54 & 10,0 \\
High risk & 6 & \\
\hline Parity & 28 & 46,7 \\
Primipara & 32 & 53,3 \\
Multipara & & \\
\hline Level of education & 4 & 6,7 \\
Low & 56 & 93,3 \\
High & & \\
\hline
\end{tabular}

The characteristics of the respondents in this study were mostly at a low-risk age of $54(90.0 \%)$. The majority of parity, namely multipara, is $32(53.3 \%)$, for the majority of high education level is $56(94.4 \%)$, and for the sex of the majority of respondents are female 32 (53.3\%). B. Bivariable Analysis

The bivariable analysis was carried out to determine the relationship between independent variables, namely infant massage giving to the dependent variable, namely weight gain in infants.

1) Differences in infant weight before and after treatment in the treatment and control groups
3,570 , and after it was found, the average increased was 3,648 gr. It has seen the difference in the mean between before and after an increase that is equal to $78.33 \mathrm{gr}$. In the statistical test results obtained $p$ value of 0.001 in the intervention group and 0.02 in the control group, it can be concluded that there is a significant difference between the baby's weight gain before and after treatment.

2) Comparison of infant weight gain in the treatment and control groups

TABEL 3. INDEPENDENT T-TEST FOR GIVING INFANT MASSAGES TO BABY'S WEIGHT GAIN

\begin{tabular}{|l|c|c|c|c|c|}
\hline \multicolumn{1}{|c|}{ Variable } & $\begin{array}{c}\text { weight gain } \\
\text { Mean }\end{array}$ & $\begin{array}{c}\Delta \\
\text { Mean }\end{array}$ & $95 \% \mathrm{CI}$ & t-test & $p$ value \\
\hline $\begin{array}{l}\text { Intervention } \\
\text { group }\end{array}$ & $-263,33 \pm 135,2$ & $-185,0$ & $-252,80-(-117,20)$ & $-5,46$ & 0,001 \\
\hline Control group & $-78,33 \pm 127,1$ & & & & \\
\hline
\end{tabular}

From the results of the independent t-test, statistical test p-value was 0.001 . The results of the statistical tests showed that there were significant differences in the two study groups. The mean difference in mean in the group 
the treatment group giving infant massage compared to the control group (95\% CI: -252.80 - (117.20).

\section{DISCUSSION}

\section{A. Differences in infant weight before and after treatment in the treatment and control groups}

Weight is a general description of nutritional status. A newborn neonate will be weighed within a few minutes after birth. The results of these bodyweight measurements are the basis for monitoring changes in body weight during the neonatal period. Changes in body weight during the neonatal period occur as a result of fluid transfer from intracellular to extracellular. Increased extracellular fluid in neonates causes salt and water diuresis in the first 48-72 hours - excessive extracellular fluid production results in physiological weight loss in the first week of life. Loss of fluids in neonates must be balanced by providing adequate nutrition to prevent dehydration or lack of calories. (Beckmann, B et al., 2014)

Baby's weight is the result of an increase or decrease in all tissue in the body, including bones, muscles, fat, body fluids, and others. The baby's weight is used as the best indicator to determine the nutritional condition and growth and development of children. According to WHO (2003), adequate body weight gain in the 2nd week for babies is $15 \mathrm{gr} /$ day. Exactly the weight gain for the age of the baby who was born quite months ( 37 to 40 weeks) is $30 \mathrm{gr} /$ day or will reach 250-300 gr/week. The Indonesian Pediatrician Association (IDAI) states if a newborn baby will experience weight loss in the first week of life. For babies who get formula milk, then the weight loss is 5 percent, whereas for babies who are breastfed, then the weight loss is more significant, which is 7 percent. All that can happen in the first 72 hours of life, and After that, the weight will go back up before the age of two weeks.

Data on the positive effects of baby massage, mostly derived from the results of studies on premature babies conducted since 1970 at the Touch Research Institutes at the Miami Medical Scholl, according to Dr. Tiffani Field and colleagues in Roesli (2001), massage in premature babies will have a positive impact including increasing the baby's weight $47 \%$ more days.

The activity of the vagus nerves influences the mechanism of absorption of food Field and Schanberg's (1986) research in Roesli (2007) shows that infants who are massaged have an increase in vagus nerve tone (the 10th brain nerve) which will cause an increase in the levels of the absorption enzymes in gastrin and insulin. Thus, the absorption of food will be better. That is why the weight of a baby who is massaged increases more than those who are not massaged. The next study was carried out by Diego et al. (2005), which states that massage therapy in premature infants can increase infant weight gain, increase vagal tone and gastric motility during and immediately after massage. Gastric totality and vagal tone are significantly related to body weight. Besides, the activity of the vagus nerve increases the volume of ASI. Food absorption is better because the increased activity of the vagus nerve causes the baby to starve quickly so that it will nurture more often to the mother. As a result, more milk will be produced. As is known, more milk will be produced if more and more are requested. In addition, mothers who massage their babies will feel calmer, and this has a positive impact on increasing the volume of milk.

Factors that influence changes in weight for infant massage are breastfeeding, gestation period, and neonatal excretion. Several factors can increase the baby's weight in addition to infant massage, namely: child nutrition, child health, immunization, genetic, housing, environmental sanitation, chromosomal abnormalities, socio-economics, medicine. (Beckmann, B et al., 2014) This is by the research of Juwitasari et al. (2018) about the effect of massage on bodyweight improvement in 0-12 Month-Old babies. So that the average difference between the two values is 0.3313 , it can be concluded that there is an increase in the baby's weight after the intervention.

Another study by Dewi et al. (2011) about the Effect of massage stimulation on weight gain in full-term infants. The result was that the median weight gain in the massage group was 1230 grams, while in the control group, it was 830 grams $(\mathrm{P}=0.028)$

\section{B. Comparison of infant weight gain in the treatment and control groups}

Karbasi et al. (2013) state that infant massage can effectively be used as a way to increase a baby's weight and is a safe non-medical measure if done. These results are in line with research by Field et al. (2004), which showed that the increase in body weight in the group of term infants who were massaged for one month was 1130 grams, meaning that the weight gain was approximately 37.67 grams per day.

Research by Dewi et al. (2011) about the Effect of massage stimulation on weight gain in full-term infants. Massage stimulation is done by the mother once a day for four weeks. Massage stimulation was given to 30 term infants and their weight gain compared to 31 control infants who did not receive massage. The result, weight gain in term infants in the massaged group, was significantly higher than in the control group after four weeks.

Baby massage has been known as a solution to facilitate the growth and development of babies that have an impact on optimizing blood flow, normalizing the heartbeat, maintaining digestion, and enhancing immunity. Massage interventions will maintain adequate nutrition by increasing the absorption of macronutrients and micronutrients by stabilizing basal metabolism and inducing insulin and adrenaline secretion and preventing cortisol secretion. Baby massage causes an increase in vagus nerve activity and will stimulate digestive hormones, including insulin and gastrin. Insulin plays a role in metabolism, causes an increase in carbohydrate metabolism, glycogen storage, synthesis of fatty acids, amino acid synthesis of protein synthesis. So insulin is an important anabolic hormone that works in various tissues, including liver, fat, and muscle. Increased insulin and gastrin can stimulate function digestion so that absorption 
of food juices becomes better. Better intake of food will cause the baby to starve quickly, and therefore, babies are more likely to breastfeed. As a result, milk production will be more. (Juwitasari et al., 2017)

In a Review of Randomized Controlled Trials of Massage in Preterm Infants, most studies have shown significantly higher daily or overall weight gain during the study period in the massage group compared to the control group while some studies did not show statistically significant differences in weight gain between the two groups (Anna and Niemi K, 2017).

Other research The Effect of Massage on Weight Gain of Low-Weight Hospitalized Infants: A Randomized Clinical Trial, as many as 45 LBW neonates were randomly allocated into the experimental and control groups. Three times a day for 15 minutes, each session is given in 5 days for the experimental group. Infant weights were measured in both groups on day 5 . The result of weight gain in the experimental group was significantly higher than in the control group. This study was a randomized clinical trial. (Johari et al., 2016).

\section{CONCLUSION}

There are differences in the baby's weight before and after the intervention is given both in the treatment group and the control group. There is a difference in birth weight gain in babies given massage compared to the control group.

\section{ACKNOWLEDGMENTS}

Thanks to the chairman of the Muhammadiyah Palembang STIKes, the Head of the P2M institution, that has provided the funding for this research through the Hibah STIKes MP.

\section{REFERENCES}

[1] Anna and Niemi K. (2017). Review of randomized controlled trials of massage in preterm infants. MDPI, 4(21):1-14.

[2] Beckmann, B., Ling, W., Herbert, P., Laube, W., Smith, P., Casanova, R., Chuang, A., Goepfert, R., Hueppchen, A. \& Weiss, M. (2014).Obstetrics and gynecology seventh edition.New York: The American College Of Obstetricians and Gynecologies.

[3] Creasy, K.R., Resnik, R., Iams, D.J., Lockwood, J.C., Moore, R.T. \& Greene, F.M. (2014).Maternal-fetal medicine principles and practice seventh edition. Elsevier Saunders: Book Aid International

[4] Dewi NN, Soetjiningsih, Prawirohartono EP. (2011). Effect of massage stimulation on weight gain in full term infants. Paediatr Indones, 51(4):202-6.

[5] Dieter, I.N., Field, T., Hernandez-Reif, M., Emory, K. E. \& Redzepi. (2003). Stable preterm infants gain more weight and sleep less after five days of massage therapy. J Pediatric Psychology, 28 (6)

[6] Edmond, K. \& Bahl Rajiv. (2006). Optimal feeding of low birth weight infants: technical review. United Kingdom: World health organization cataloguing in publication data.

[7] Ferber, G.S., Feldman, R., Kohelet, D., Kuint, J., Dollberg, S., Arbel, E. \& Weller, A. (2004). Massage therapy facilitates mother-infant interaction in premature infants. J Infant Behav and Dev. 28: 74-81.

[8] Field, T., Diego, A., Hernandez-Reif, M., Deeds, O. \& Figuereido, B. (2006). Moderate versus light pressure massage therapy leads to greater weight gain in preterm infants. J Infant Behav and Dev, 29(4): 574-578.
[9] Johari S, Haghgou HA, Daemi M, Rezaeiyan T, Neja ZM. (2016) The Effect of Massage on Weight Gain of Low-Weight Hospitalized Infants: A Randomized Clinical Trial. Physical Treatments, 5(4):205-210.

[10] Juwitasari and Harista DR. (2017). The Effect of Massage on Body Weight Improvement in 0 - 12 Month-Old Babies. Advances in Health Sciences Research (AHSR), volume 2: 15761.

[11] Karbasi SA, Golestan M, Fallah R, Golshan M, Dehghan Z. (2013). Effect of body massage on increase of low birth weight neonates growth parameters: A randomized clinical trial. Iran J Reprod Med, 11(7): 583-588.

[12] Kelmanson, A.I. \& Adulas, I.E. (2006). Massage therapy and sleep behavior in infants born with low birth weight. Complementary Therapies In Clinical Practice, 12: 200-205.

[13] Perry. E., Hockenberry, J., Lowdermilk, L., \& Wilson D. (2010).Maternal child nursing care, fourth edition. Canada: Mosby Elsevier

[14] Rangey, S.P. \& Sheth, M. (2014). Comparative effect of massage therapy versus kangaroo mother care on body weight and length of hospital stay in low birth weight preterm infants. International Journal of Pediatrics.

[15] Roesli U. (2001). Pedoman pijat bayi prematur \& bayi usia 0-3 bulan. Jakarta: Tribus Agriwidya.

[16] . (2007). Pedoman Pijat Bayi. Jakarta: Tribus Agriwidya

[17] Santrock, J.W., 2007. Child Development, Elevant Edition (Perkembangan Anak) Edisi Kesembilan. Jakarta: Erlangga.

[18] Soedjatmiko.2006. Pentingnya Stimulasi Dini Untuk Merangsang Perkembangan Bayi dan Balita Terutama Pada Bayi Resiko Tinggi. Sari Pediatri

[19] Soetjiningsih, dan Ranuh, N. Gde. 2014. Tumbuh Kembang Anak. Edisi 2.EGC. Jakarta

[20] UNICEF \& WHO. (2004). Low birth weight: Country, regional and global estimates. New York: UNICEF.

[21] Vickers, A., Ohlsson, A., Lacy, J. \& Horsley, A. (2009). Massage for promoting growth and development of preterm and/or low birth weight (review). The Cochrane Library, issue 1.

[22] WHO. (2003). Kangaroo mother care: A Practical guide. Geneva.

[23] Yesinel, S., Aldemir, Y.E., Kavuncuoglu, S. \& Yildiz, H. (2014).Evaluation of growth in very low birth weight preterm babies.Turkish archives of pediatrics, 49 (4): 289-98. 